\title{
マニラ都市圏における土地利用と人口の空間的分布に関する研究*
}

\section{Study on the Spatial Distribution of Land Use and Population in Metro Manila}

佐々木 恵一**、Noriel Christopher C. Tiglao***、田村 亨****、斎藤 和夫****** by Keiichi SASAKI, Noriel Christopher C. Tiglao, Tohru TAMURA and Kazuo SAITOU

1.はじめに ${ }^{1223)}$

マニラ首都圈 (17 市町村から成る)の面積は東京都区部とほ ぼ同じ、636km²゙あり、そこに全国人口の約 $13 \%$ に当たる 945 万人 (1995 年国調)が住んでいる。そして、農村部から流入す る人口は年 3\% (1980～1995)の伸びを続け、2010 年には 1,200 万人になると予測されている。これらの流入する人々の 多くはスコッター(不法占拠者)と言われ、その数は 300 万人に も達しており、彼らの居住地区の人口密度は 1,000 人haを超え てその環境の悪化が指摘され続けているが、これに対する有 効な対策が提案されていない。

これに対し公共サイドは、首都圈開発局(MMDA)を中心に 既に居住環境改善に乗り出しており、また都市計画制度にもと づいた土地利用誘導を行おうとしているが、ともに遅々として 進まない状況である。これは、人口の流入を規制する法案がな いこと、また同開発局とそれを構成する市町村との権限調整が 上手くいっていないことが原因と言われている。この調整を含 めてマニラ首都圏の都市政策立案に資するためには、まず土 地利用と人口の関係を定量的に把握する必要がある。

マニラ都市圈では、JCAの開発調査(MMUTIS: 1997)の中 で、将来人口の張付きについての検討を行っているが、土地 利用別人口密度原単位による予測に止まっている 4)。このた め、土地利用政策によって誘導される人口動態については、 十分な検討がされていない状況にある。そこで本研究は、フィ リピン大学交通研究センター(以下、NCTS と記す)が数年にわ たって作成してきた'86 年、'96 年のマニラ都市圈土地利用デ 一タを使って、土地利用と人口の空間的分布を分析することを 目的とする。具体的には、土地利用の特性分析を行うとともに、 人口変動を予測するためのニューラルネットワーク(以下、 NN と記す)モデルを提案する。

\section{2. マニラ首都圈の土地利用データ}

NCTS で収集・整備した土地利用データは、バランガイと呼 ばれる基礎的行政単位(平均人口 3,000 人)で調査したもので

\footnotetext{
${ }^{*}$ keyword: 都市計画、土地利用

** 正会員, 修士, 函館工業高等専門学校 環境都市工学科 T042-8501 函館市戸倉町 14 番 1 号 TEL \& FAX : 0138-59-6481

***フリピン大学 交通研究センター

**** 正員 室蘭工業大学建設システム工学科 助教授

***** 正員 室蘭工業大学建設システム工学科 教授
}

ある。調査は航空写真を用いて区画の全ての建物・道路等を GIS 上に入力したものを地図として出力し、調査員が区画をま わって、この地図上に建物現況利用状況を記入していくという、 莫大な作業により作成されたものである。

この土地利用データは、表 1 に示す 19 分類で構成されてお り、1986年にマニラ首都圈のほぼ全域にわたって調査された。 本分析においては、バランガイ単位のデータをマニラ都市圈 の計画ゾーン(235)に集計して用いた。また、土地利用の時系 列変化を把握するために、土地利用変化が大きいと考えられ るバランガイを対象として、1996年に同様の調査が害施された。 その数は、 54 ゾーンである。また人口データについては国勢 調査が実施された 1986 年と 1996 年のデータを使用して以降 の分析を試みた。

\section{3. 土地利用と人口に関する基礎的集計}

全マニラ都市圈の土地利用構成 (19 分類)を表 1 に示す。こ れより、住宅地区が $27 \%$ 、オープンスペースが $15 \%$ 、道路用 地 9\%、農業用地 9\%、草原 7\%、工業用地 6\%と続いてい 表 1 マニラ都市圈の土地利用構成比

\begin{tabular}{l|r|r} 
Metro Manila & 面積(ha) & 構成比(\%) \\
\hline Residential & 15,200 & 26.93 \\
Commercial/Business & 1,616 & 2.86 \\
Industrial & 3,531 & 6.26 \\
Government/Quasi-Public & 448 & 0.79 \\
Educational & 1,057 & 1.87 \\
Sports/Athletics & 610 & 1.08 \\
Health/Welfare & 238 & 0.42 \\
Park/Recreational & 331 & 0.59 \\
Religious/Cemetery & 718 & 1.27 \\
Transport/Service Facility & 899 & 1.59 \\
Military & 1,114 & 1.97 \\
Agricultural Land & 5,202 & 9.22 \\
Grassland & 3,784 & 6.70 \\
Forest & 759 & 1.34 \\
Water Related & 2,453 & 4.35 \\
Open Space & 8,432 & 14.94 \\
River/Creek & 1,307 & 2.32 \\
Road & 5,240 & 9.28 \\
Unknown & 3,501 & 6.20 \\
Under Construction & 0 & 0.00 \\
\hline \hline Total & 56,438 & 100.00
\end{tabular}


表 2 地域別土地利用構成比

\begin{tabular}{|c|c|c|c|c|c|c|c|c|}
\hline Metro Manila & $\begin{array}{r}\text { Metro } \\
\text { 面積(ha) }\end{array}$ & $\begin{array}{l}\text { Manila } \\
\text { 構成比(\%) }\end{array}$ & $\begin{array}{r}\text { Mani } \\
\text { 面積 (ha) }\end{array}$ & $\begin{array}{l}\text { la City } \\
\text { 構成比 (\%) }\end{array}$ & $\begin{array}{l}\text { Inside } \\
\text { 面積 (ha) }\end{array}$ & $\begin{array}{l}\text { EDSA } \\
\text { 構成比 (\%) }\end{array}$ & $\begin{array}{r}\text { Outsid } \\
\text { 面積 (ha) }\end{array}$ & $\begin{array}{l}\text { de EDSA } \\
\text { 構成比 (\%) }\end{array}$ \\
\hline Residential & 15,200 & 26.93 & 1,420 & 36.64 & 4,161 & 40.79 & 9,620 & 22.71 \\
\hline Commercial/Business & 1,616 & 2.86 & 406 & 10.49 & 615 & 6.03 & 595 & 1.40 \\
\hline Industrial & 3,531 & 6.26 & 188 & 4.85 & 641 & 6.28 & 2,702 & 6.38 \\
\hline other & 30,851 & 54.66 & 1,158 & 29.88 & 3,413 & 33.45 & 26,281 & 62.04 \\
\hline Road & 5,240 & 9.28 & 703 & 18.15 & 1,372 & 13.45 & 3,166 & 7.47 \\
\hline Total & 56,438 & 100.00 & 3,874 & 100.00 & 10,201 & 100.00 & $\overline{442,363}$ & $\overline{100.00}$ \\
\hline
\end{tabular}

る事が分かる。

本研究において、これら 19 分類を表 2 に示す 5 分類に集計 した。集計に際して、旧市街地であるマニラ市ブロック、環状 4 号線(通称 EDSA 通り)の内側で市街化が進んでいるブロック (マニラ市を除く)、EDSA の外側で市街化が進行しつつあるブ ロックの $3 つ に$ 分け、 5 分類の妥当性を検䛉た。表 2 から分か

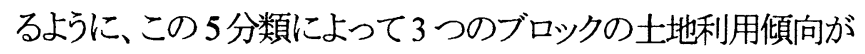
把握できる。

次に人口についてまとめる。図 1 は、1986 年と1996年の 10 年間における人口密度の変化を図化したものである。これより EDSA の内側において、人口密度の伸びが鈍化し、密度が減 少している地区が多いことが確認できる。

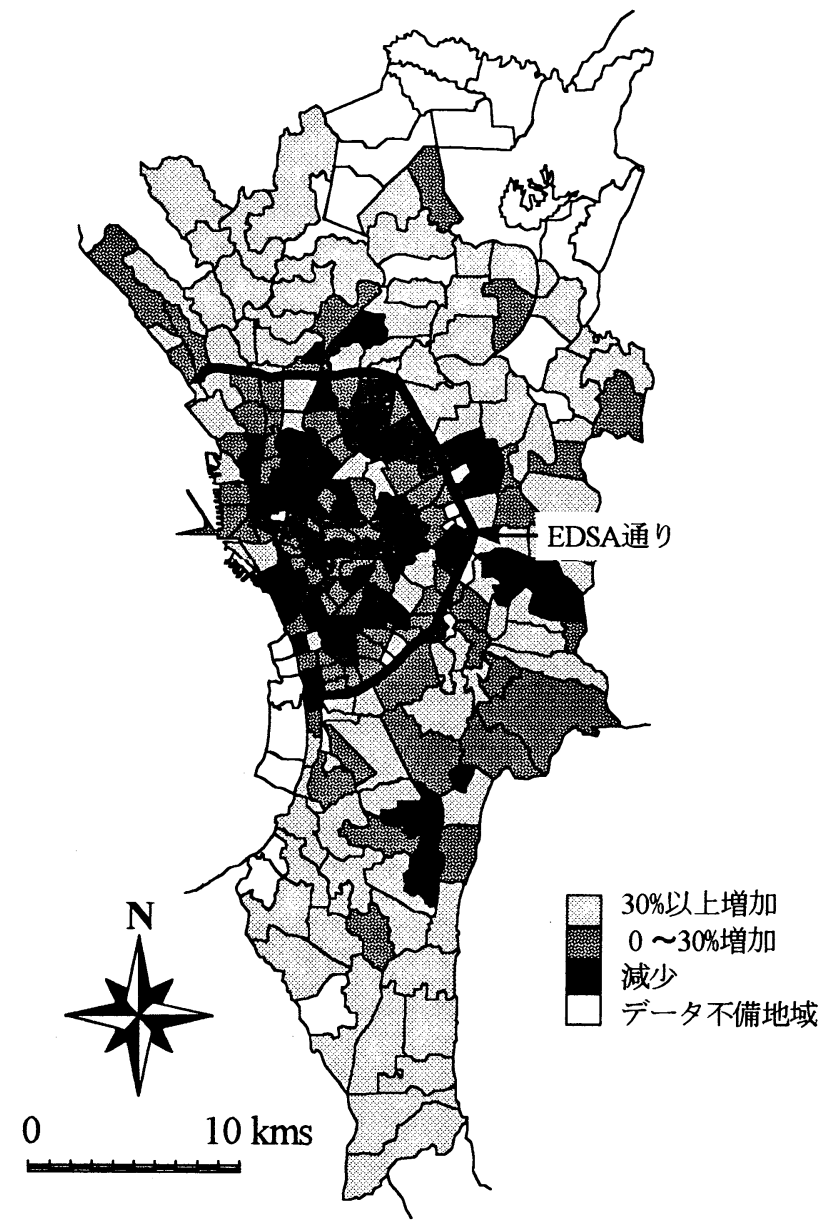

図 1 人口変化図

土地利用と人口の関係を分析する際、1996年の土地利用調 査が実施された地域が 54 地域であったため、全市を対象にし た分析は行わなかったが、マニラ市の中心部にあった商業地
域が大きく減少し、東方八大きな商業立地があり、商業地が郊 外部へ移動したことが確認された。また、人口の変動も同様に 中心部から東方への人口移動が見られ、商業地の移動に伴う 人口の移動があったことが予測される。

\section{4. 土地利用デー夕による地区の分類}

'86 年と’96 年の土地利用データをプールして 289 地区('86 年 235 地区と’96 年 54 地区の合計 289 地区)について主成分 分析し、その主成分得点をクラスター分析することで、グルー プ分けを行った。

表 3 は主成分分析の結果を示したものであり、2 軸までで $73 \%$ の現象を捕らえられることが分かる。また、各軸の主成分 得点加、1 軸目は住宅地增進軸、2 軸目は都市化軸(商業地 や工業地の増進に関わる軸) と言える。

表 3 主成分得点係数表

\begin{tabular}{c|r|r}
\multirow{2}{*}{} & \multicolumn{2}{|c|}{ 主成分得点係数 } \\
\cline { 2 - 3 } & 第一主成分第二主成分 \\
\hline 住 宅 & 0.495 & 0.224 \\
商 業 & -0.080 & -0.549 \\
工 業 & 0.124 & 0.393 \\
その他 & -0.465 & -0.001 \\
道 路 & 0.191 & -0.381 \\
\hline \hline 需与率 & 40.569 & 32.388 \\
累積寄与率 & 40.569 & 72.958
\end{tabular}

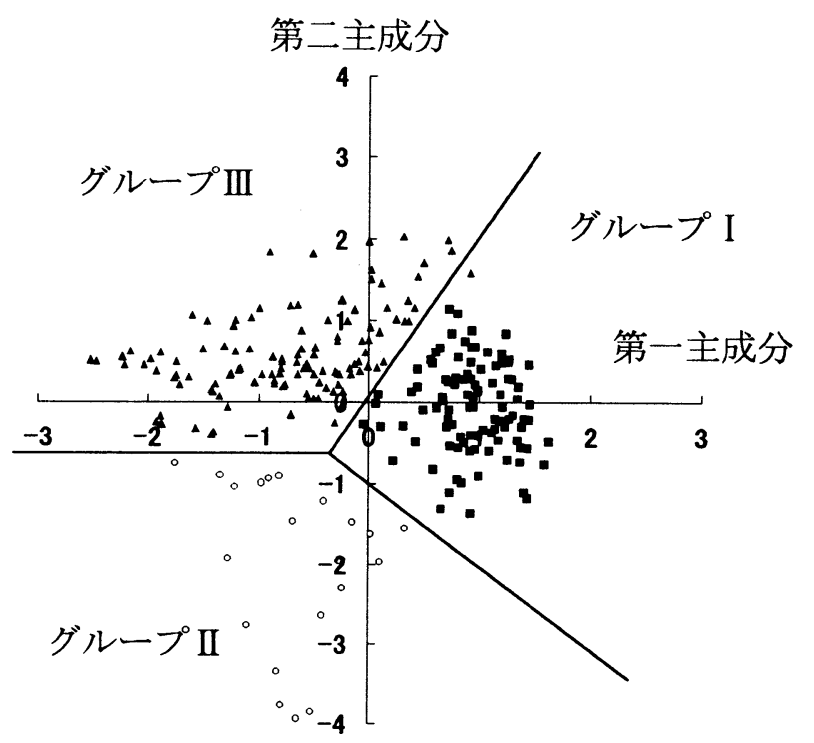

図 2 第一、第二主成分の配置図 


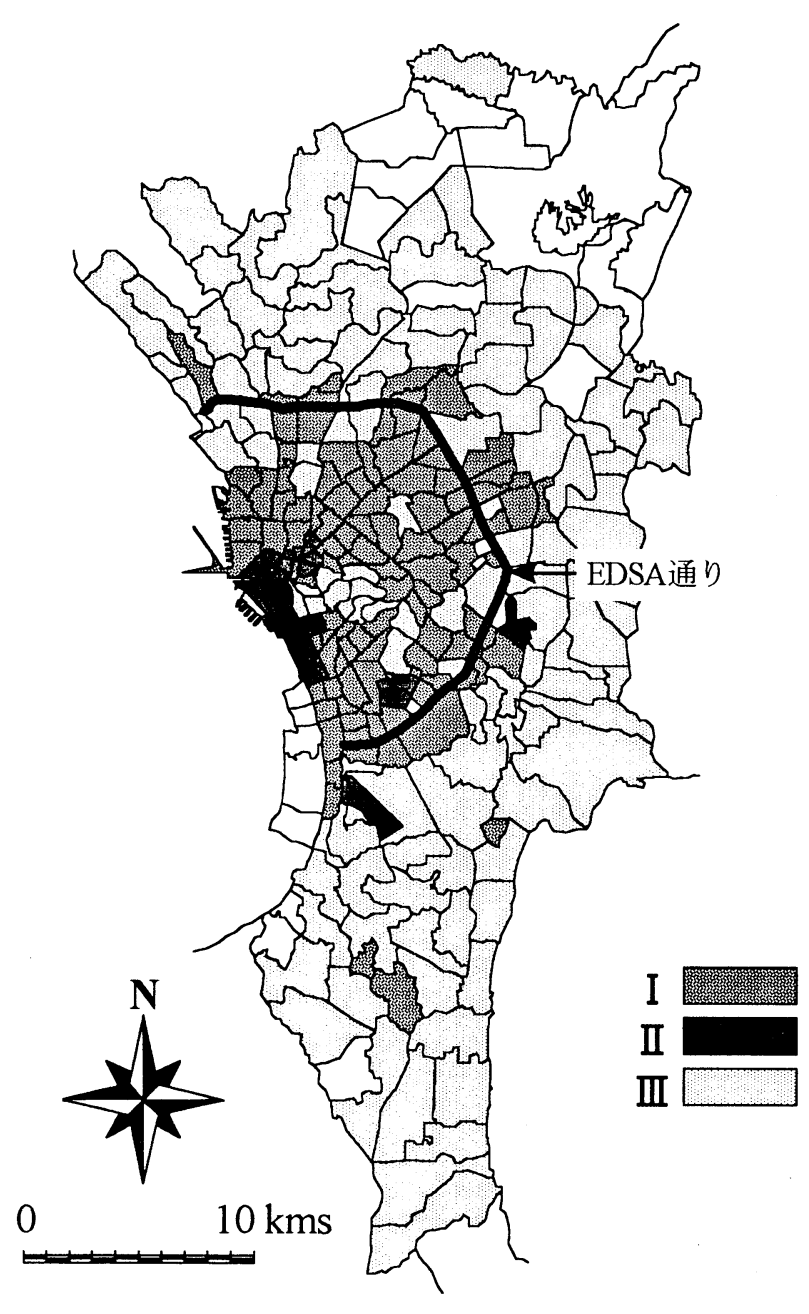

図 3 土地利用分類

地区別の主成分得点をクラスター分析した結果、3つに分類 し、分析を行った。3つのグループと軸との関係を図化したもの が図 2 である。これより、グループ I は 1 軸が正の方向にある 住宅地増進地区(既成市街地区)、グループIIは 1 軸が負、2 軸が正の方向、すなわち都市化が進み住宅地の増進が少な い地区(旧市街地)、グループIIIは、1軸が負、2 軸が負の方向、 住宅地増進も都市化も進んでいない地区(新興市街地) と分類 できる。1986 年の土地利用について、この 3 グループの空間 位置を示したものが図 3 である。

表 4 は各グループごとの土地利用を集計したものである。こ の表 4 と表 2 を比較してみると、表 4 の方が地区特性をよく表 現していることが分かる。例えば、旧市街地(表 2 のマニラ市、 表 4 のグループ II )の比較では、商業·業務用地が多く、住宅 用地が少なくなっている傾向は表4においてより顕著に表れて いる。また、治安の維持と環境の改善を目的として開発されて いるビレッジはグループ I に属する。ビレッジとは、ある特定 の地域を塀などで囲い、内部を住宅地専用に開発した居住シ ステムのことである。このビレッジの内部へ入るには、いくつか のゲートを通らなくてはならず、その際通行証が必要となる。そ のため、通過交通が出来ないため騒音や大気污染といった環 境保全が可能である反面、都心部に存在しているため交通の 妨げにもなっている。また、外部からの進入が極端に低いため、 スコッターの進入も抑制できる。これらの地域は住宅地の占有
率が高い反面、人口密度が低いのが特徵であるの。 表 4 分類別土地利用構成比

\begin{tabular}{|c|c|c|c|c|c|c|}
\hline & & & \multicolumn{2}{|c|}{ II } & \multicolumn{2}{|c|}{ III } \\
\hline & I & 構成比 & II & 構成此 & III & 構成比 \\
\hline Residential & $\overline{5,825}$ & $55.1 \%$ & $\overline{154}$ & $10.6 \%$ & $\overline{8,242}$ & $23.1 \%$ \\
\hline Commercial/Business & 674 & $6.4 \%$ & 344 & $23.7 \%$ & 482 & $1.4 \%$ \\
\hline Industrial & 599 & $5.7 \%$ & 25 & $1.7 \%$ & 2,680 & $7.5 \%$ \\
\hline other & 1,730 & $16.4 \%$ & 649 & $44.7 \%$ & 21,422 & $60.1 \%$ \\
\hline Road & 1,737 & $16.4 \%$ & 280 & $19.3 \%$ & 2,796 & $7.8 \%$ \\
\hline & 10,565 & 1.00 & 1,452 & 1.00 & 35,621 & 1.00 \\
\hline
\end{tabular}

次に、この 3 つのグループ（I 、II 、III) と、人口密度との関 係をまとめる。図 4 は横軸に図 1 に示した人口密度変化をとり、 縦軸に各グループごとの地区数の構成割合 (各グループごと で $100 \%$ )を示したものである。これより、旧市街地(II)は人口 密度が $0 \sim 10 \%$ 減之 10〜30\%減が多く、既成市街地( I )では、 0 10\%増が、そして、新興市街地(III)では、 $30 \%$ 以上増が多 くなっていることが分かる。これは、グループ I では人口密度 が低、地域(100 人ha 以下)の地域が減少しており、300 人ha 以上の地域では増加の傾向にある。このため前者はビレッジ の人口動向にあると考えられ、後者はスコッターの流入が進ん でいる地域と考えられる。グループIIについては、人口の流 出が高く、旧市街地の人口流出が激しい地域である。また、進 行市街地之位置づけたグループIIIIは人増加が激しいことが わかる。なお、グループごとの平均人口密度は、I グループ 314.2 人ha、IIグループ 144.9 人ha、IIIグループ 74.3 人ha なっている。

以上の結果より、土地利用分類により、マニラ市は 3 つのグ ループに分けて捕らえられることが分かった。そして、それぞ れのグループと人口との関係も把握できる可能性が高いことが 示唆された。

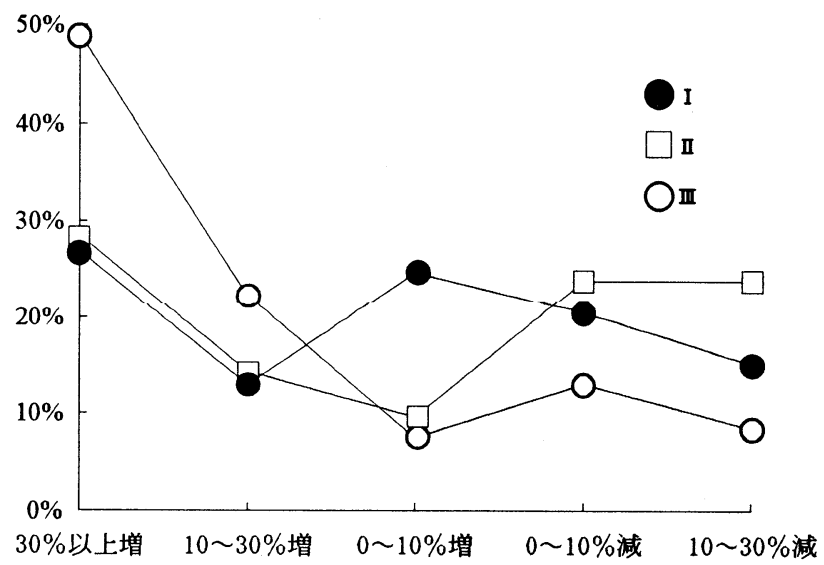

図 4 分類別人口変化動向

\section{NNモデルによる土地利用-人口モデルの構築}

NN モデルを用い人口を推計することを目的とした理由は、 従来の分析方法が政策変数である土地利用による人口の抑制 に主眼が置かれているため、本研究の対象地域のような場合 には適用が困難と考えたからである。そこで土地利用による人 口抑制策の議論の前に、土地利用から人口を再現できるモデ 
ルの構築が必要と考えた。具体的には、2つのモデルを構築 した。それは、(1)1 地区の土地利用状況を入力変数しし、人口 を出力するモデル(単地域 NN モデルと呼ぶ)、(2)対象地区と 周辺の地区の土地利用状況を入力变数とし、人口を出力する モデル(多地域 NN モデルと呼ぶ)である。

以下に詳述するが、単地域 NNモデルについてはマニラ都 市圈全域対象に適用したが、良好なモデルは構筑できなかっ た。そこで、現在市街化されている地域のうち旧市街地を除い た地域(人口密度が中程度で日本上似ている地域)を対象に、 NN モデルを構築した。この地域を選定した理由は、人口密度 が高い旧市街地ではスコッター居住が多く、土地利用変化と人 口変化の現象が捕らえにくいと考えたためであり、逆に新興市 街地(人口密度が低い地域)では、大規模ビレッジ開発が進ん でおり、その開発動向と土地利用変化とを結び付けることがデ 一夕収集単位上、工夫がいると考えたためである。多地域 NN モデルは単地域 NN モデルでは適用を避けた地域について も適用し、分析を行った。また、人口データについてもスコッタ 一人口をどのくらいの精度で把握しているのか（国勢調査デー 夕を使用)が不明なため、その使用については十分な注意が 必要であった。以下に具体的な分析をまとめる。

\section{(1)単地域モデル}

NNモデルを用いて土地利用-人口モデルを構築した研究と しては、土井らが3層NNモデルを土地利用分析に用い、その 内部状況把握のための方法を提案している》。また荒木らは、 土地区画整理事業の施行パターンによって都市成長過程の 違いを説明している8。本研究では、土地利用状況をパターン 情報しして捉え、NN モデルによりそのパターンを学習すること とした。モデル作成においては 4 章のグルーピングにおける 既成市街地地区(グループ I )を対象とし、このうち’86 年と’96 年の 2 時点のデータがそろっている 19 地区を対象として分析 することとした。

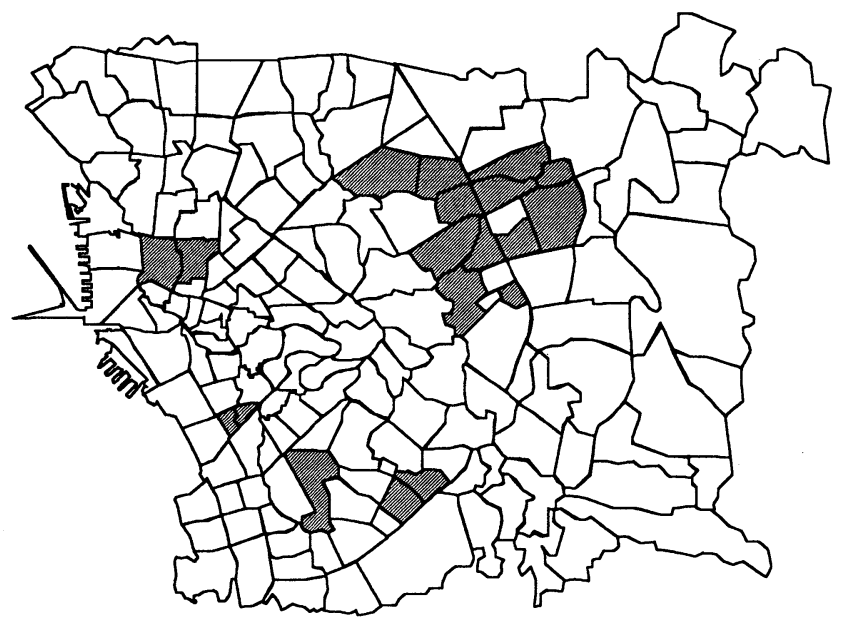

図 5 単地域 NN モデル適用地域

分析においては、土地利用データ (5 分類)を説明変数とし て地区の人口密度を目的変数とする重回帰モデルと土地利用 データを入力層、人口密度を出力層とする $\mathrm{NN}$ モデルの二つ を構築する。そして各モデルの現状再現性と将来予測性から モデルの有效性を検討することとした。また'86 データを用い
て重回帰モデルを構築した結果は(1)式の通りである。

$$
\begin{aligned}
y=0.221 x_{\text {res }}-0.020 x_{\text {comm }}+0.311 x_{\text {indl }} \\
+0.122 x_{\text {other }}+0.141 x_{\text {road }}-2011
\end{aligned}
$$

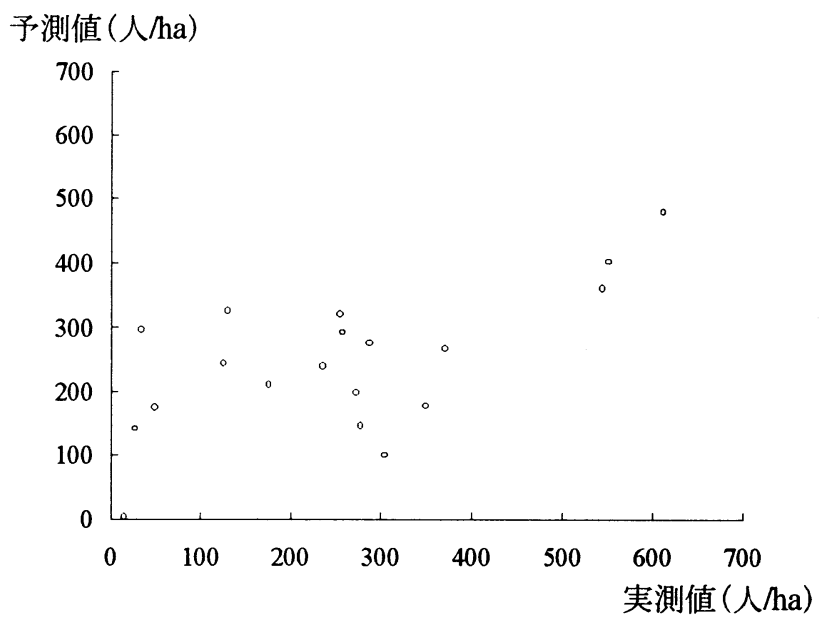

図 6 重回帰相関図

ここで、

\section{$y$ : 人口密度 (人/ha)}

$x_{i}$ : 単位面積当たりの土地利用 $i$ の面積 $\left(\mathrm{m}^{2} / \mathrm{ha}\right)$

重回帰係数は 0.25 であり、重回帰モデルでは予測值と実測 值の相関係数は 0.68 であった。 NN モデルでは、入力層(5)中間層(8)-出力層(1)のニュー口構成を考えモデル構築した。ま た、中間層素子数の決定に当たってはAICにより行った。推計 した結果は図 5 に示寸様に、現状再現性についての相関係数 は 0.9699 と高い值が得られた。

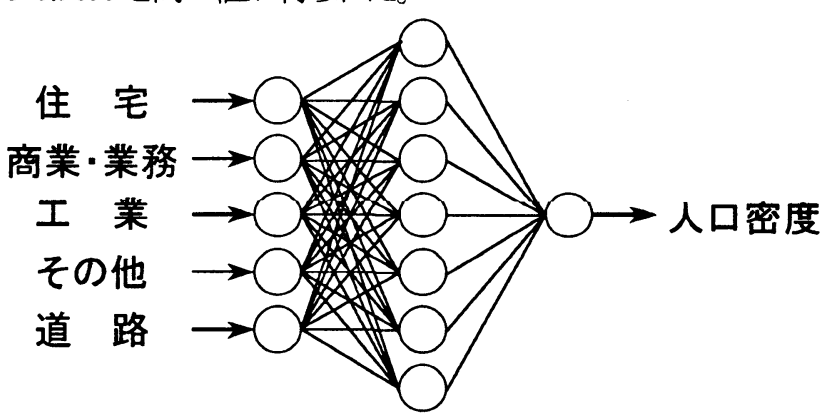

図 7 単地域 $\mathrm{NN}$ モデルの構造

以上、 2 つのモデルを比較すると、NNモデルの現状再現性 が高いことが分かる。

次にNNモデルを用いてモデルの時間移転性を検討するこ ととした。具体的には、'86NN 年モデルを用いて、'96 年の土 地利用データを入力し、'96 年の人口密度を推計することとし た。その結果、予測值と実測值との相関係数は 0.93 となり、NN モデルの時間移転性が検証できた。しかし、本モデルは人口 密度中程度の地区に対し、土地利用変化に対する人口密度変 化を表せられるモデルであり、スコッター地域については適用 ができなかった。 

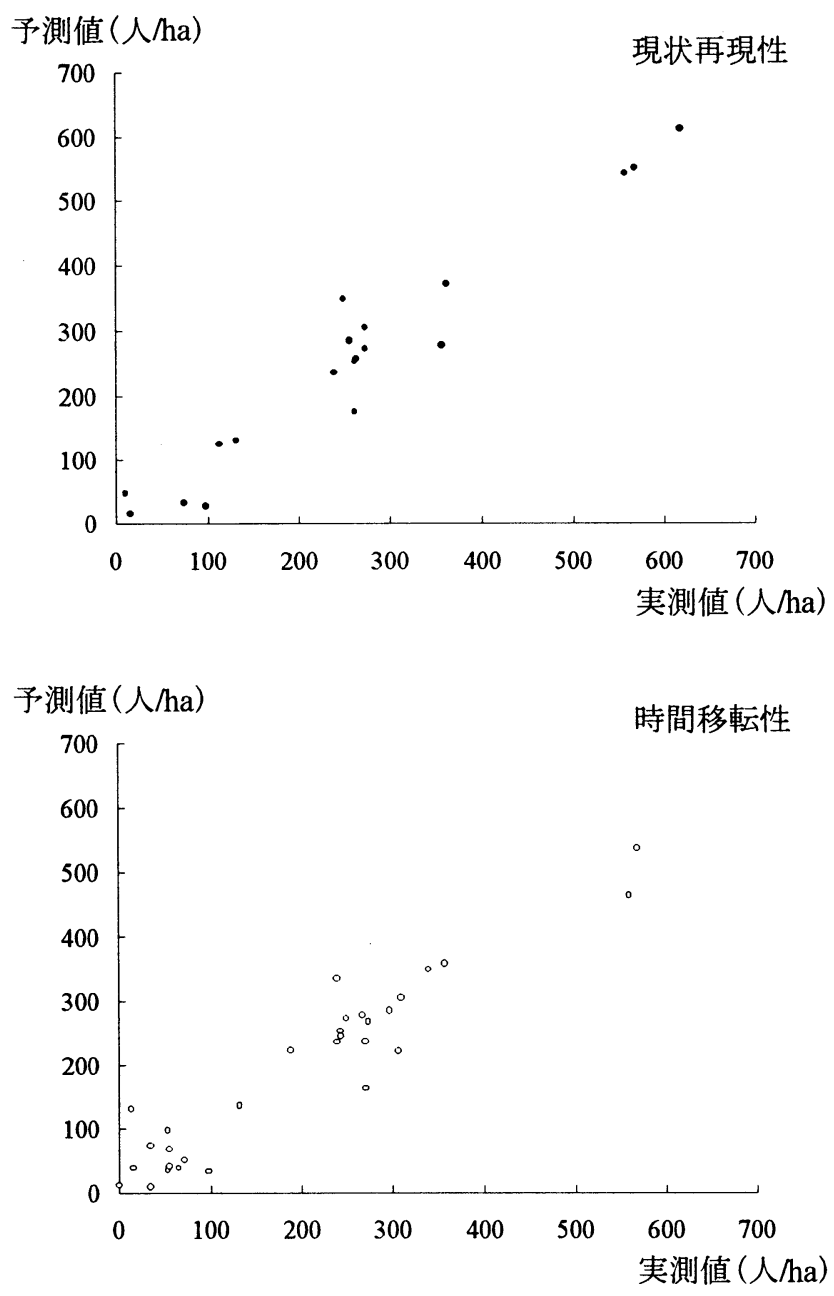

図 8 単地域 $N N$ モデルの相関図

\section{(2)多地域モデル}

都市の発展過程と拡大は空間相互作用と都市の発展の履 歴によって決まると考えられる。例えば、スコッターは都市内の 空地に不法占拠するのだが、先行して普通住宅地が形成され ている場合、空き地に余裕がないため、爆発的なスコッターの 増加はない。

また、マニラ首都圈はマニラ市を中心に放射線状に都市が 拡大しつつある。これは中心部の新規立地が不可能なため、 住宅地が郊外化し、これにともない人口も郊外化するためであ る。しかし、都市の郊外化は他の土地利用も大きく作用しなが ら進む。今回用いたデータから考えると、1985 年にマニラ市中 心部にあった商業地が東方のEDSA 通り沿いに移動し、これと 同時に人口が移動している。この様な都市内人口移動を把握 するため、他地域との関係を学習した NN モデルの並列処理 によるモデルの構築を考えた。

大貝らはメッシュデータを用い NN モデルの各入力素子に 隣接するメッシュのデータを入力することにより、空間の情報を 取り込んだ 9)。本研究では土地利用変化の影響が周辺地域の 住環境を変え人口が決まり、人口が増加していくとその人口分 布の度合いで住宅の郊外化が進展する。すなわち、都市内で の人口移動は空間相互作用とその波及効果により時間発展し ていくと考えた。

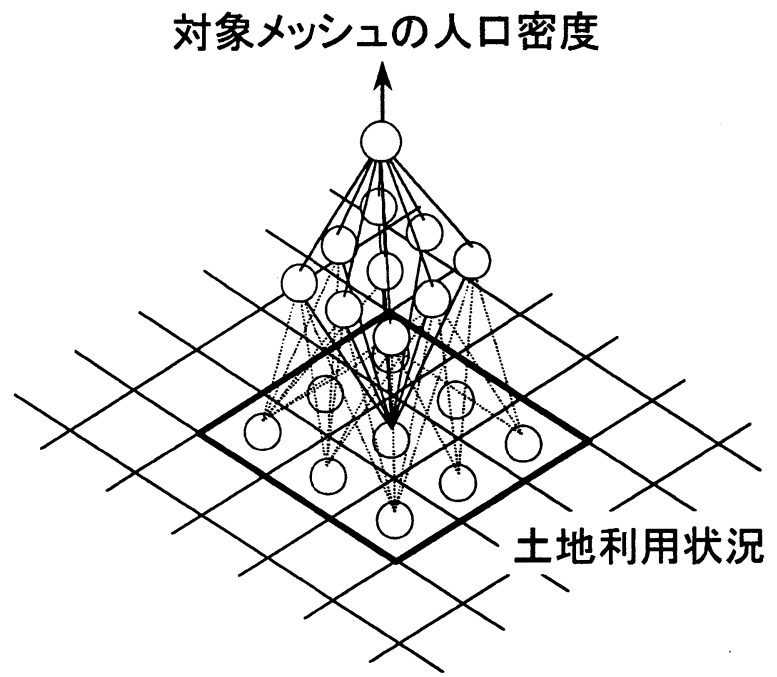

図 9 他地域との関係を学習した NN モデル 多地域モデルについては対象地域に点在するデータをメッ シュ状のデータに加工し、人口を出力する対象メッシュの土地 利用とともに、隣接するメッシュの土地利用情報も同時に入力 する。具体的な入力デー夕は土地利用状況を 5 項目とし、 9 個 のメッシュの土地利用状況を同時に入力し、対象メッシュの人 口密度を出力することとした。そのため NN モデルの構造は入 力層(45)-中間層(19)-出力層(1)とした。また、このモデルにつ いても中間層素子数決定には AIC を用いた。

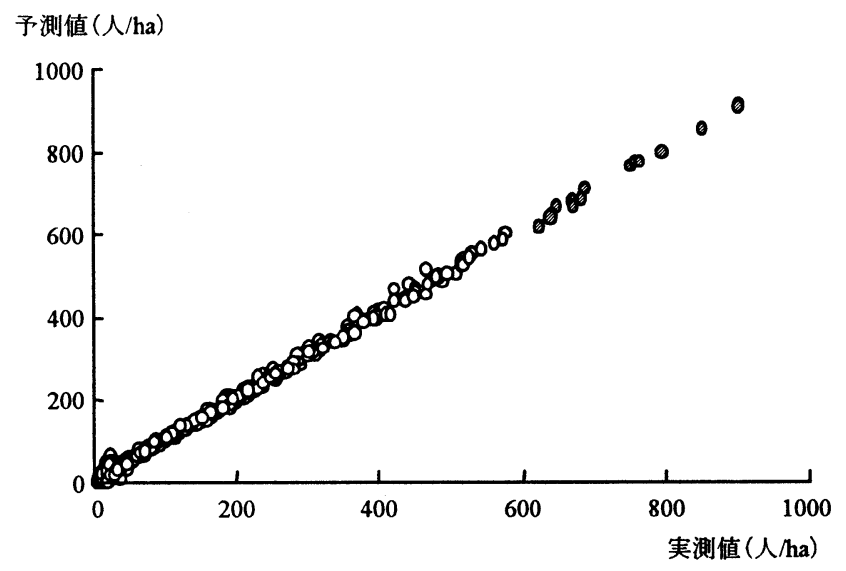

図 10 多地域NN モデルの相関図

図 10 は多地域 NN モデルの相関図である。相関係数は 0.9993 と高く、また単地域NNモデルと比較しても大きな值とな つている。特に、単地域 NN モデルでは再現が出来なかった 高密度人口地域についてもよく適合している。

図 11 は構築したモデルの感度分析を行ったものである。こ れは土地利用を 5 分類としてモデル構築しているため、一般 住宅地における道路占有率、工業・その他の占有率を現行の 值に固定しておいて(それぞれ 10\%,0\%,0\%)、商業施設占有 率と住宅占有率に応じて、人口密度がどのように変化するモデ ルとなっているのかを調べるためである。

この図より、商業施設が多いほど人口密度が高いことがわか る。また、住宅占有率が 25\%を超えると人口密度は急激に増 加し、住宅占有率 $40 \%$ 、商業施設占有率 $40 \%$ で最大となる。 また、商業施設が $0 \%$ のさ、人口密度は住宅占有率に関係な 
く100 人ha 以下と非常に小さな值である。これは、モデルがビ レシジ地区の土地利用と人口の関係を把握できているためと考 えられる。

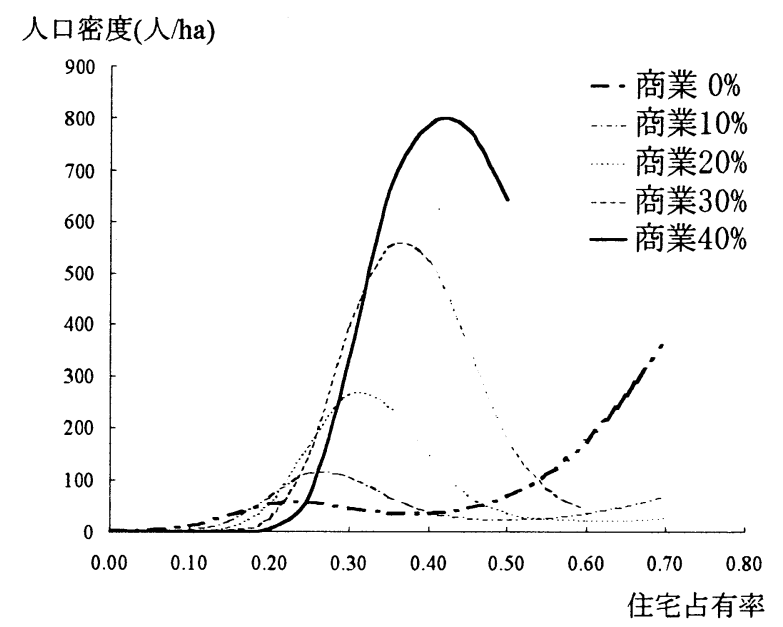

図 11 感度分析

\section{6. 結論}

本研究の目的は、フィリピンマニラ都市圈の土地利用政策 による人口分布の誘導を検討するための基礎的な分析として、 土地利用と人口の空間的分布を分析したものであり、以下のこ とが明らかとなった。

(1)土地利用を 5 つに分類することで、マニラ首都圈の土地 利用特性に応じた地区のグループ分け(3つ)ができること を明らかにした。

(2)3 つのグループと人口密度の変化とを対応させたところ、 この 3 分類で土地利用と人口密度との関係を把握できる 可能性が高いことを示した。

(3)人口密度中程度の地区に単地域 NN モデルを適用し、 土地利用変化に対する人口密度変化を表現できるモデ
ルが構筑できた。さらに、多地域モデルを構筑することで マニラ首都圈全域について現状を再現するモデルを構 筑できた。

今後の課題は、モデルへの時間の取り込みである。これに 関しては、NN モデルの並列処理による自己組織化と時間発 展を試みている。

本研究は、日本学術振興会「アジア地域の環境保全」の研 究助成を得て進めたものである。

\section{《参考文献〉}

1)岩田、外尾:マニラ市の民間都市開発の先進性と後進性、土木計画 学研究·講演集 No.15(1), pp225-232, 1992.11

2)岩田、外尾: 大規模民間都市開発における協力分担方式一マニラと バンコクのケースー、都市計画論文集 No,29,pp409-414, 1994

3)フイリピンの都市・住宅計画関連法令および制度(1997.4)、フィリピン 都市計画研究会編

4) JCA: Metro Manila Urban Transportation Integration Study (MMUTIS) Progress Report II , MMUTIS 1997.

5) ICA: A Factbook on Metro Manila's Transportation and Traffic Situation (Prepared by MMUTIS Study Team), MMUTIS 1997.

6)西岡、フィリピンにおける囲郭住居システムの成立に関する研究、 都市計画論文集 No32, pp517-522, 1997

7)土井、紀伊:ニューラルネットワークを用いた知識獲得手法の開発と 土地利用分析への適用、土木学会論文集 No.590/IV-39,31-42, pp3142, 1998.4

8)荒木、宮下、柎: 地方中枢・中核都市の土地区画整理事業施行パ ターンに関する基礎的研究、都市計画論文集 No32, pp211-216, 1997

9)大貝、河合:メシシュデータを用いた小売業売場面積推計ニューラ ルネットワークモデルの開発、都市計画論文集 No33, pp337-342, 1998

\section{マニラ都市圏における土地利用と人口の空間的分布に関する研究}

佐々木 恵一、Noriel Christopher C. Tiglao、田村 亨、斎藤 和夫 マニラ首都圈の人口は地方部からの人口流入によって、1980 年の 592 万人から 1995 年には 945 万人へと増加した。 現在、この人口増加はスコッター地区やスラム街の拡大を引き起こし、深刻な環境問題となっている。土地利用政策によ る人口誘導のための既存の都市モデルは、開発途上国特有のデータ欠如一の配慮が為されていなかった。そこで本 研究はマニラ首都圈の 1986 年、96年における土地利用データを用いて土地利用と人口の空間的分布について分析す る。

\footnotetext{
Study on the Spatial Distribution of Land Use and Population in Metro Manila

by Keiichi SASAKI, Noriel Christopher C. Tiglao and Tohru TAMURA, Kazuo SAITOU

The population of Metro Manila has increasing from 5,926 thousand in 1980 to 9,454 thousand in 1995 because of migration from local regions. Now increase of population causes expansion of squatter and slum area and will cause more serious environmental problems. Upon reviewing previous urban model for predicting the population increasing impact of the change of land use, authors shows that most of the notable models did not pay due attention to the lack of data in developing countries. Then, this research is analyzing the spatial distribution of land use and population, using a land use data of Metro Manila in 1986 and 1996.
} 